Abstracta Iranica Abstracta Iranica

Revue bibliographique pour le domaine irano-aryen

Volume 28 | 2007

Comptes rendus des publications de 2005

\title{
"A note on ethnicity and ethnic groups in Iran ». Iran and the Caucasus, vol. 9, n' 1, 2005, pp. 37-41.
}

\section{Anne-Sophie Vivier-Muresan}

\section{OpenEdition}

1 Journals

\section{Édition électronique}

URL : http://journals.openedition.org/abstractairanica/10832

DOI : 10.4000/abstractairanica.10832

ISSN : 1961-960X

Éditeur :

CNRS (UMR 7528 Mondes iraniens et indiens), Éditions de l'IFRI

\section{Édition imprimée}

Date de publication : 15 mai 2007

ISSN : 0240-8910

\section{Référence électronique}

Anne-Sophie Vivier-Muresan, « «A note on ethnicity and ethnic groups in Iran ». Iran and the Caucasus, vol. 9, n 1, 2005, pp. 37-41. ", Abstracta Iranica [En ligne], Volume 28 | 2007, document 495, mis en ligne le 18 septembre 2007, consulté le 25 septembre 2020. URL : http://journals.openedition.org/ abstractairanica/10832 ; DOI : https://doi.org/10.4000/abstractairanica.10832

Ce document a été généré automatiquement le 25 septembre 2020.

Tous droits réservés 


\title{
" A note on ethnicity and ethnic groups in Iran ". Iran and the
} Caucasus, vol. 9, $\mathrm{n}^{\circ}$ 1, 2005, pp. 37-41.

\author{
Anne-Sophie Vivier-Muresan
}

1 L'A. prétend présenter en quelques pages la situation ethnique prévalant en Iran aujourd'hui. Il s'agit surtout d'un texte polémique visant en fait à minimiser la diversité ethnique de l'Iran et les questions qu'elle soulève : les non persanophones sont réduits à $15 \%$ de la population, le terme de «minorité ethnique » est dénoncé comme non pertinent et, en guise de conclusion, l'A. insiste sur la dissolution naturelle et sans heurt des identités particulières dans le creuset de l'identité nationale.

INDEX

Thèmes : 16.1. Iran

\section{AUTEURS}

ANNE-SOPHIE VIVIER-MURESAN

Paris 